\title{
Učitel profesionál, nebo učitel poklepem?
}

\author{
Pavel Doulík
}

\begin{abstract}
Loňský rok nám přinesl zcela nečekanou situaci $\mathrm{v}$ podobě pandemie onemocnění covid-19. A pandemie nastoupila se vším, co k ní (bohužel) patří. Celý svět se ocitl ve stavu restrikcí, lockdownu a řešení problémů, které se vlastně nevyskytly od konce 2 . světové války. A to už je nějakou dobu, proto jsme zapomněli, co vše to může pro naši společnost znamenat. A školství v tom samozřejmě není výjimkou. I na něj pandemie dolehla v plné síle. $\mathrm{O}$ tom, co vše se ve školství muselo změnit a čemu jsme se museli přizpůsobit, se už napsalo mnoho. $S$ určitou nadějí jsme se upínali k roku 2021, který by mohl přinést jistou naději na zvrat $v$ průběhu epidemie, a to zejména díky plošnému očkování. Dnes je více než jasné, že i letošní rok bude velmi náročný a že problémy, se kterými jsme se potýkali v roce 2020, si přeneseme i do toho letošního. Jen jsme možná o trochu zkušenější $\mathrm{v}$ tom, jak si s těmito problémy poradit. Ale abychom ne vše připisovali pandemii, ve školství a ve vzdělávání vůbec přináší rok 2021 novinky, na které by se nemělo zapomínat.
\end{abstract}

A cože nového nás v současné době vlastně potkalo? Velmi diskutovaná a ne zcela vítaná novela zákona o pedagogických pracovnících (vizte samostatný diskusní příspěvek v tomto čísle), revize rámcových vzdělávacích programů základního vzdělávání s velkým vítězstvím informatiky či právě zahájená diskuse a snad i dokonce reforma pregraduální přípravy učitelů... To jsou hlavní momenty, které se před námi s nástupem roku 2021 vynořily. O každém z nich by se dala napsat 
spousta textu, já se ale zastavím u toho posledního a vlastně nejaktuálnějšího. U další reformy pregraduální přípravy učitelů.

Ano, u další. Snad žádná jiná vysokoškolská příprava pro budoucí profesi se nereformuje tak často jako právě učitelství. Nevím, zda je to tím, že příprava učitelů musí neustále akceptovat nové trendy, nebo tím, že je příprava učitelů u nás prostě dlouhodobě nekvalitní a je třeba hledat různé cesty $\mathrm{k}$ její optimalizaci. Anebo že by za tím stálo i něco málo politických ambicí? Ne, do žádných spekulací se pouštět nechci, jen bych $\mathrm{k}$ tomu rád uvedl několik svých vlastních (subjektivních sic!) postřehů.

Za dobu svého působení na akademické půdě, tedy 20 let, jsem se aktivně účastnil již několika reforem přípravy budoucích učitelů. Počínaje nuceným strukturováním učitelských studií v roce 2004 a konče třeba definováním standardů přípravy učitelů ze strany MŠMT (a dalších pedagogických pracovníků), kdy se učitelství stalo regulovanou profesí. Jak tomu již bývá, ne každá změna musí být $\mathrm{k}$ lepšímu, ale akademický svět je velmi flexibilní, a tak jsme se $\mathrm{v}$ př́ipravě učitelů uměli přizpůsobit mnohým novotám. Nyní přichází ministerstvo $s$ dalším nápadem - musíme přizpůsobit př́ípravu budoucích učitelů požadavkům Strategie 2030+, tedy chápejme to tak, že pregraduální př́íprava učitelů musí reagovat na nové výzvy, které školní vzdělávání přináší. To je jistě chvályhodné, na druhou stranu se ptám, zda se toto náhodou neděje. Vždyt́ každá udělená akreditace musí zrcadlit aktuální potřeby svého oboru. Jako pozitivní vnímám to, že ministerstvo už nemluví o reformě pedagogických fakult, ale o prŕípravě učitelů na fakultách připravujících učitele (FPU). Vždyt těchto fakult je v České republice více než 30 a samotné pedagogické fakulty, kterých je devět, jsou jen částí tohoto celku. Na druhou stranu jsou to ústřední hráči v př́pravě budoucích učitelů, nebot́ z podstaty věci si přípravu učitelů berou jako své hlavní poslání. Nyní přichází ministerstvo s časově specifikovanou reformou, kdy chce od února do června za pomoci dvou expertních skupin prosadit dvě klíčové změny $\mathrm{v}$ prŕípravě učitelů - sjednotit profil absolventa učitelství na všech FPU a posílit praxe.

Upřímně, nejedná se o žádné novinky. Není tomu tak dlouho, kdy se dvě odborné skupiny (nejprve jedna více prakticistní, následně pak více akademická) snažily vytvořit standard začínajícího učitele (věc, po které se dlouho volá) a s tím související kariérní řád učitelů. Standard začínajícího učitele je přesně to, co vymezuje profil absolventa učitelství - konec jeho odborné přípravy a začátek jeho působení na školách. Standardů začínajícího učitele se vytvořilo (i za mohutné podpory evropských peněz) několik, nikdy však standard přijat nebyl a stal se spolu s kariérním řádem další odloženou složkou. Kolik jich jen už máme? 
A navyšování praxí? Další z evergreenů. Byl jsem osobně přítomen množství jednání na různých grémiích, kde se řešily standardy MŠMT pro pregraduální př́ípravu učitelů. Od velmi sympatického začátku jednání, kdy se zdálo, že standardy mohou př́pravě učitelů na různých FPU pomoci, se diskuse postupně rozostřovala, až se výsledný dokument stal ani ne snad kompromisem, jako spíše výsledkem toho, který z aktérů se ozýval nejhlasitěji. A jedním z neuralgických bodů byl i podíl praxe a její podoba. Od původní představy významného podílu praxí (mimochodem, už tehdy jsem tvrdil, že učitelství je typický profesní studijní program a podíl praxe má být zásadní) jsme se dostali na nějaký $8 \%$ podíl za celou pětiletou př́ípravu. Její podoba pak nebyla řešena vůbec. Mimochodem, byly to tehdy nepedagogické fakulty připravující učitele, které si prosadily významné snížení praxí. Racionálně to chápu, tyto fakulty kladou větší důraz na př́pravu v jednotlivých aprobačních oborech, vždyt to souvisí s jejich profilem. Ale je tu ještě jedna zásadní věc - pokud bude chtít ministerstvo opět rozehrát hru o změnu standardů a navyšovat podíl praxí, bude muset zároveň hledat zdroje, ze kterých budou praxe financovány. Pedagogické fakulty a vůbec FPU se svými napjatými rozpočty budou další prostředky hledat jen těžko. MŠMT navíc přichází s nápadem reformovat pregraduální př́ípravu učitelů v době, kdy většina FPU má díky institucionální akreditaci studijní programy schválené na dobu 10 let. Nechci být pesimista, ale nemyslím si, že by se fakultám chtělo po dvou třech letech programy předělávat a znovu procházet akreditačním kolečkem at' už u rady pro vnitřní hodnocení, nebo na národním akreditačním úřadu. To už by byl trochu masochismus.

A propos, národní akreditační úřad. Ono není vždy lehké sladit požadavky úřadu na akreditace studijních programů a jejich standardy s tím, po čem touží ministerstvo. Někdy je to př́ímo Sofiina vola, komu vlastně vyhovět. Proto si držme palce, aby zamýšlená reforma, se kterou ministerstvo přichází, nebyla jednou z dalších, které překryje prach, ale aby skutečně pregraduální přípravu učitelů posunula směrem, který je potřebný a žádoucí. I když, minimálně pedagogické fakulty jsou na reformy natolik zvyklé, že se ve finále přizpůsobí každé reformě. Otázka je, zda to povede $\mathrm{k}$ lepším učitelům (ale jaký učitel je vlastně lepší?)...

A co nás čeká v tomto čísle Pedagogiky? Je to zejména pět studií, dále dva velmi aktuální diskusní příspěvky, dvě knižní recenze a nekrolog. První ze studií je práce kolektivu pod vedením Petra Urbánka, která se zabývá výzkumem klimatu učitelského sboru. Ale jak vyplývá z názvu (Výzkum klimatu učitelského sboru: potenciál smišené metodologie), o něco více než zjištění konkrétního klimatu učitelského sboru jde o představení a analýzu možnosti tzv. smíšeného designu výzkumu. V pedagogickém výzkumu spolu kvalitativní a kvantitativní metodo- 
logie koexistuje dlouhou dobu a ve většině případů dáváme přednost jednomu, nebo druhému přístupu. Snaha o tzv. smíšený design se objevuje v posledních 15 letech a stále ještě není v pedagogickém výzkumu pevně ukotvena. Proto považuji uvedenou studii za velice př́nosnou v tom, že ukazuje na konkrétním prrípadu cestu, jak smíšenou metodologii realizovat, a také to, že může přinést velmi zajímavé výsledky.

Další studií je příspěvek autorů Libuše Samkové, Lukáše Rokose, Jana Petra a Ivy Stuchlíkové nazvaný Teoretický model pro formativní hodnocení prí badatelsky orientované výuce matematiky a prírodopisu. Badatelsky orientované vyučování je hitem posledních několika let a ve výuce zejména př́rodovědných předmětů nachází své pevné místo. Podobně v poslední době, a to zejména v souvislosti s online výukou na základních a středních školách, prožívá jakousi renesanci i formativní hodnocení. Ne že by se dříve nepoužívalo, ale dnes je daleko více skloňováno a je na takový typ hodnocení kladen větší důraz. Proto spojení obou těchto fenoménů - badatelsky orientované výuky a formativního hodnocení - přináší zajímavý pohled. Což ostatně autoři ve své studii dokazují a vytváří modifikovaný komunikační model. Tím se ještě více teoreticky ukotvuje formativní hodnocení právě kontextu individualizující a problémové výuky, kterou „inquiry based learning beze“ sporu je.

Problematikou specifických otázek implementace intervenčních programů pro podporu rozvoje pregramotnostních dovedností se ve třetí studii zabývají autorky Petra Šedinová a Gabriela Málková Seidlová. Autorky představují koncepční a teoretická východiska pro tvorbu pregramotnostně orientovaných programů, postupy jejich konstrukce a jejich implementaci do praxe. Ačkoli se jedná o studii založenou na teoretické analýze bez empirického výzkumu, autorky představují přehled poznatků z mezinárodního výzkumu i z výzkumu v českém a slovenském prostředí. Tím se vytváři dostatečný základ, aby se čtenář v problematice implementace intervenčních programů zorientoval a vytvořil si rámcový pohled na toto téma.

Od oblasti preprimárního a primárního vzdělávání ke střednímu odbornému vzdělávání přecházíme ve čtvrté studii tohoto čísla časopisu Pedagogika. Autoři Pavel Pecina a Peter Mirinič se v ní věnují kvalitě výuky odborných předmětů a jejímu výzkumu s využitím didaktických kazuistik. Kvalita výuky je pojem, který je dlouhodobě řešen různými aktéry školství (od odborné po decizní sféru) a který je často vykládán různými způsoby. Jak autoři sami uvádějí, vymezení kvality výuky je velmi složité a jde o systematickou záležitost. Já osobně velmi vítám fakt, že se autoři zaměřují na odborné předměty na středních školách, protože tato oblast stále není dostatečně zkoumána. Využití tzv. didaktických kazuistik pak potvrzuje kvalitativní metodologii, kte- 
rou autoři využili. $Z$ jejich výsledků tak sice nelze vytvářet obecné závěry, ale svými kazuistikami přinášejí zajímavý pohled na problematiku kvality výuky na středních odborných školách.

Poslední, pátá studie autorů Aleše Bednárka, Gabriely Mynářové, Marka Václavíka a Ivy Červenkové se zabývá výukovými zdroji u žáků osmých ročníků základních škol. Kromě tradičních výukových zdrojů, jako jsou učebnice, se autoři věnují i moderním (digitálním) zdrojům. Popsaný výzkum je realizovaný, jak je typické pro studie v tomto čísle časopisu Pedagogika, kvalitativní metodologií. Polostrukturované rozhovory byly realizovány na jaře 2020, tedy v době, kdy v České republice začala pandemie onemocnění covid-19, což vedlo mimo jiné k uzavření škol. Proto by bylo zajímavé zjistit, jak se změnily typy výukových zdrojů a jejich využívání právě v souvislosti s přechodem na online vzdělávání. Je to pro autory jistě zajímavý námět, jak tyto změny dále zkoumat.

Za velice důležitý a aktuální považuji publikovaný diskusní př́spěvek k novele zákona o pedagogických pracovnících, se kterým bude jistě souhlasit většina odborné veřejnosti, jež má učitelství jako oblast svého zájmu. Autoři zcela věcně a bez emocí pojmenovávají neuralgická místa novely, přičemž místo toho, abychom posilovali učitelství jako plnohodnotnou profesi, vymysleli jsme vlastní „,̌eskou“ cestu, kterak z kohokoli učitele udělat jedním papírem. Věřím, že př́spěvek přiměje $\mathrm{k}$ zamyšlení i ty kompetentní osoby, které o novele zákona rozhodují. Mimochodem, přijde mi celkem paradoxní řešit s ministerstvem reformu pregraduální př́ípravy učitelů (jak o tom píšu výše) a zároveň legislativně ukotvit, že učit může i člověk bez této pregraduální př́ípravy. Tak trochu to př́ipomíná pohádku o chytré horákyni. Jestli by nakonec nebylo lepší než vytvářet tyto paradoxy uznat učitelství jako plnohodnotnou regulovanou profesi, kde je magisterském studium zaměřené na učitelství esenciální podmínkou. Př́padně se zkusím přihlásit u ředitele nejbližší nemocnice $s$ tím, že bych rád pracoval jako lékař. Vždyt' jsem vystudoval biologii a chemii a ta práce mě prostě baví.

Druhý diskusní příspěvek se věnuje současné situaci v realizaci inkluzivního vzdělávání na českých školách. S předchozím př́íspěvkem ho spojuje to, že se kriticky vyjadřuje k aktuálním intervencím MŠMT. Poukazuje na to, že inkluze jako prostředek rovných př́ležitostí pro všechny žáky se stala obětí politických hrátek. A jakmile vyhrává politika nad odborností, není to nikdy pozitivní signál, což autoři v př́íspěvku také popisují.

První číslo letošního ročníku časopisu Pedagogika ještě uzavírají dvě recenze na aktuálně vydané publikace. První recenze je od Stanislava Štecha, který nás seznámí s knihou "Nová škola“ v meziválečném Československu ve Zlině: Ideje, aktéri, mista, jejímiž autory jsou zkušení odborníci v oblasti dějin pedagogiky, Tomáš Kasper a Dana Kasperová. Druhou recenzi pak obstaral Jan Průcha. 
Jedná se o recenzi velmi rozsáhlé publikace s názvem Velké dèjiny zemí Koruny české: Školství a vzdělanost, za jejímž vznikem stojí celkem 12 autorů a kterou editoval Miroslav Novotný. Čtenáři tak získají kritický pohled na knižní novinky v oblasti pedagogiky.

Vážená čtenářko, vážený čtenáři, věřím, že Vás aktuální číslo časopisu $P e-$ dagogika zaujme, že si v něm najdete to, co Vás (nejen odborně) zajímá, a že si jím zpestříte ne př́liš optimistické „covidové“ dny. Přeji př́íjemné čtení a pevné zdraví!

prof. PaedDr. Pavel Doulik, Ph.D.

Univerzita J. E. Purkyněv Ústí nad Labem, prorektor pro vnèjsí vztahy;

e-mail:pavel.doulik@ujep.cza 